\title{
3. PARTICIPATION
}

Persons interested in participating in this symposium are requested to sulanit an abstract ( $\max .250$ words) in one of the six designated categories. Abstracts must include author's name, current mailing address, telephone, and institutional affiliation. Abstracts must be sent to the symposium coordinator by or before SFPTEMBER 1, 1983; participants will be notified by approximately NOVEMBER 1, 1983; working copies of symposium papers must then be mailed to the symposium coordinator by or before MARCH 15, 1984 in order to confirm participation.

A volume of essays will be published in conjunction with this symposium. Participation in the symposium is not required, nor does it guarantee publication. Those wishing to submit a paper for this volume are requested to follow the instructions above, but indicate "For Publication only" in the upper right corner of the abstract.

The coondinator of the Hegel/Whitehead Symposium is:

$$
\begin{aligned}
& \text { Professor George R. Luras, Ir.. } \\
& \text { Department of Philosophy, } \\
& \text { University of Santa Clara, } \\
& \text { Santa Clara, CA } 95053 \text {, U.S.A. }
\end{aligned}
$$

An introductory paper is available on request.

\section{Hegel soclety of America: Conference on 'Hegel's Phillosophy of Spirit'}

\section{First Call for Papers}

The Hegel Society of America will hold its eighth biennial oonference at Russell Sage College in Troy, New York, on 4-6 october 1984. The conference theme is Hegel's philosophy of spirit. Papers should focus on Hegel's Encyclopedia, volume III, or consider other works in relation to its themes and issues. It is planned that the program will be balanced among subjective, objective, and absolute spirit.

Papers should be subnitted (four copies to the Program Chair, Professor Peter G. Stillman, Department of political Science, Vassar college, Poughkeepsie, New York 12601, by 29 February 1984. Fach will be refereed by the Program Comittee, and a decision rendered around 15 May 1984.

Sutmission and acceptance of a paper assumes that the author will present it in no more than 30 minutes reading time at the conference, will submit a final draft for editing into the proceedings within a month after the conference, and will reserve first publication for the proceedings. 